\title{
Muscarinic Receptors in Chromaffin Cell Cultures Mediate Enhanced Phospholipid Labeling but Not Catecholamine Secretion
}

\author{
*Stephen K. Fisher, †Ronald W. Holz, and *Bernard W. Agranoff \\ *Neuroscience Laboratory, Mental Health Research Institute, and Department of Biological Chemistry, University \\ of Michigan; and $\nmid$ Department of Pharmacology, University of Michigan Medical School, \\ Ann Arbor, Michigan, U.S.A.
}

\begin{abstract}
The addition of either carbachol or muscarinic agonists to cultured bovine adrenal chromaffin cells results in a selective stimulation of phosphatidate (PhA) and phosphatidylinositol (PhI) labeling from ${ }^{32} \mathrm{P}_{\mathrm{i}}$ and $\left[{ }^{3} \mathrm{H}\right] \mathrm{glycerol}$ that can be inhibited by the inclusion of atropine, but not $d$-tubocurarine. In contrast, increased catecholamine secretion is observed on the addition of carbachol or nicotinic agonists and is inhibited by $d$-tubocurarine but not by atropine. Added calcium is essential for catecholamine secretion but not for stimulated phospholipid labeling. Chelation of endogenous $\mathrm{Ca}^{2+}$ with EGTA does, however, inhibit the stimulated phospholipid labeling. These results suggest that stimulated phospholipid labeling in the bovine chromaffin cell and catecholamine secretion are separate and distinct processes. Key Words: Cholinergic agonist-Muscarinic receptor-Bovine adrenal chromaffin cellPhosphatidate-Phosphatidylinositol. Fisher S. K. et al. Muscarinic receptors in chromaffin cell cultures mediate enhanced phospholipid labeling but not catecholamine secretion. I. Neurochem. 37, 491-497 (1981).
\end{abstract}

In many tissues cholinergic agonists interact with their specific cell membrane receptors and selectively enhance the labeling of two quantitatively minor phospholipids, phosphatidate (PhA) and phosphatidylinositol (PhI) (Hokin and Hokin, 1953; Schacht and Agranoff, 1972; Michell, 1975; Hawthorne and Pickard, 1979). There is a broad heterogeneity in the details of the response, and while labeling patterns reflect primarily changes in turnover, altered chemical amounts of these lipids have also been observed (Michell, 1975). In tissues such as the pancreas, parotid gland, anterior pituitary, guinea pig adrenal medulla, or avian salt gland, the activation of cholinergic muscarinic receptors leads to both a characteristic secretory response and an increased labeling of PhA and/or $\mathrm{PhI}$ from added $\left[{ }^{32} \mathrm{P}\right]$ orthophosphate (Hokin et al., 1958; Hokin and Hokin, 1967; Hokin, 1968; Oron et al.,
1975; Young et al., 1979). Although a role for stimulated phospholipid labeling in the secretory response has been suggested on the basis of such studies, differences in time courses and in requirements for extracellular calcium in various tissues are difficult to reconcile. Thus, despite extensive investigation, the physiological significance of the phospholipid labeling effect remains unknown.

In earlier studies, Trifaro $(1969 a, b)$ concluded that acetylcholine-stimulated phospholipid labeling and catecholamine secretion in slices of bovine adrenal medulla were unrelated events. In the adrenal of this species, however, cholinergic receptors coupled to catecholamine secretion appear to be entirely nicotinic (Douglas, 1975), whereas in all tissues examined to date, cholinergic agoniststimulated phospholipid labeling is mediated by muscarinic and not by nicotinic receptors (Michell,
Received January 22. 1981; accepted March 3, 1981.

Address correspondence and reprint requests to Dr. B. W. Agranoff, Neuroscience Laboratory, University of Michigan. 1103 East Huron, Ann Arbor, Michigan 48109.
Abbreviations used: DMPP, 1,1-Dimethyl-4-phenylpiperazinium iodide; MEM. Minimum essential medium; PhA, Phosphatidic acid; PhI, Phosphatidylinositol; PSS. Physiological salt solution. 
1975). A recent study indicated the presence of a small number of muscarinic receptors in bovine adrenal medulla (Kayaalp and Neff, 1979). This observation raises two possibilities: either both stimulated phospholipid labeling and increased catecholamine secretion are mediated through nicotinic cholinergic receptors in this tissue or, alternatively, bovine chromaffin cells possess both muscarinic and nicotinic receptors, and the former mediate stimulated phospholipid labeling whereas the latter mediate secretion. To distinguish between these alternatives, we have utilized a preparation of bovine adrenal chromaffin cells maintained in monolayer culture. The cells retain their original physiological, biochemical, and pharmacological characteristics and upon stimulation release catecholamines by exocytosis (Kilpatrick et al., 1980; Trifaro and Lee, 1980). Thus, they provide a useful experimental system in which these questions can be directly addressed with specific biochemical and pharmacological probes.

\section{MATERIALS AND METHODS}

${ }^{32} \mathrm{P}_{\mathrm{i}}$ (carrier-free) and $\left.2 f^{3} \mathrm{H}\right] \mathrm{glycerol}(0.5 \mathrm{Ci} / \mathrm{mol})$ were obtained from Amersham, Chicago, Illinois. ${ }^{45} \mathrm{CaCl}_{2}(37.4$ $\mathrm{Ci} / \mathrm{g}$ atom) was obtained from New England Nuclear, Boston, Massachusetts. Eagle's minimum essential medium (MEM) and fetal calf serum were obtained from GIBCO, Grand Island, New York. 5-Fluorodeoxyuridine, atropine, $d$-tubocurarine, bethanechol, muscarine, methacholine, nicotine, and 1,1-dimethyl-4-phenyl piperazinium iodide (DMPP) were obtained from Sigma Chemical Co., St. Louis, Missouri. Fungizone was obtained from Squibb, Princeton, New Jersey. Gentamycin was purchased from Microbiological Associates, Bethesda, Maryland.

Chromaffin cells, disaggregated from bovine adrenal medulla, were added to $16-\mathrm{mm}$ diameter uncoated culture wells (approximately 450,000 cells/well) containing $1 \mathrm{ml}$ of MEM medium supplemented with $10 \%$ heatinactivated fetal calf serum, $10 \mu \mathrm{M}$-5-fluorodeoxyuridine (to inhibit cell division and fibroblast proliferation), 50 $\mu \mathrm{g} / \mathrm{ml}$ gentamycin, and $2.5 \mu \mathrm{g} / \mathrm{ml}$ Fungizone (Fenwick et al., 1978; Livett et al., 1979). After $2-28$ days at $34^{\circ} \mathrm{C}$ in $5 \% \mathrm{CO}_{2}-95 \%$ air, chromaffin cells formed monolayers that contained 6-15 nmol catecholamine/well. In some preparations, a Percoll gradient was employed to purify further the chromaffin cells (Kilpatrick et al., 1980), but since there was no apparent effect on experimental results, this step was discontinued. Secretion and phospholipid labeling experiments were performed at $25^{\circ} \mathrm{C}$ in a physiological salt solution (PSS) containing $142 \mathrm{~mm}-\mathrm{NaCl}, 5.6 \mathrm{mM}-\mathrm{KCl}$, $3.6 \mathrm{~mm}-\mathrm{NaHCO}_{3}, 2.2 \mathrm{~mm}-\mathrm{CaCl}_{2}, 5.6 \mathrm{~mm}$-glucose, 0.1 $\mathrm{mg} / \mathrm{ml}$ sodium ascorbate, and $15 \mathrm{~mm}$-HEPES buffer (pH 7.4). In secretion experiments, after incubation in test solutions, the contents of the well were added to a test tube containing $56 \mu \mathrm{l}$ of $50 \%$ trichloroacetic acid (TCA). One milliliter of 5\% TCA was added to the well and the floor of the well scraped to liberate catecholamine remaining in the cells. Catecholamines (norepinephrine + epinephrine) released into the medium and in the extract of cells was measured by the method of Euler and Floding (1955). Data are expressed as the percent of the total catecholamine released into the medium at the end of the 15-min incubation.

${ }^{45} \mathrm{Ca}^{2+}$ influx was measured by incubating the cells in PSS containing ${ }^{45} \mathrm{CaCl}_{2}(0.5 \mu \mathrm{Ci} /$ assay $)$. After 5 min incubation, the radioactive medium was aspirated and cells washed twice with $1 \mathrm{ml}$ of unlabeled PSS. Triton X-100, $1 \%(0.5 \mathrm{ml})$, was then added to each well, cells scraped, and radioactivity counted after the addition of $10 \mathrm{ml}$ of ACS scintillation counting solution (Amersham, Chicago, Illinois).

In phospholipid labeling experiments, the chromaffin cells were allowed to preincubate for $30 \mathrm{~min}$ in PSS containing $15-50 \mu \mathrm{Ci}{ }^{32} \mathrm{P}_{\mathrm{i}}$ and $15-25 \mu \mathrm{Ci}\left[{ }^{3} \mathrm{H}\right]$ glycerol. After preincubation, either $0.5 \mathrm{ml}$ of $5 \%$ TCA was added to terminate the labeling (zero-time point, $\mathrm{C}_{0}$ ), or, alternatively, the radioactive medium in the wells as aspirated and replaced with either fresh radioactive medium $\left(\mathrm{C}_{1}\right)$ or fresh radioactive medium containing drug(s) (E). Unless otherwise indicated the $\mathrm{C}_{1}$ and $\mathrm{E}$ incubations continued at $25^{\circ} \mathrm{C}$ for an additional $15 \mathrm{~min}$, after which reactions were terminated by aspiration of the test solution followed by rapid addition of $0.5 \mathrm{ml}$ of $5 \%$ TCA. Cells were scraped off the bottom of the well and transferred to test tubes with an additional $1 \mathrm{ml}$ of $5 \%$ TCA. Carrier tissue (approximately $10 \mathrm{mg}$ wet wt. of adrenal medulla homogenates) was then added to each tube and allowed to precipitate for $1 \mathrm{~h}$. The precipitated pellets were obtained after low-speed centrifugation, washed with $2 \mathrm{ml}$ of cold distilled water, and the centrifugation step repeated. After aspiration of the supernatant medium, $0.5 \mathrm{ml}$ of water was added to each pellet. Lipids were extracted from the pellets with acidified chloroform-methanol, separated by TLC, and quantitated as previously described (Fisher and Agranoff, 1980). In some experiments the phospholipids were also separated by two-dimensional TLC (Marggraf, 1976; Yavin and Zutra, 1977). Three to five wells were analyzed separately for each experimental group. The results are expressed as percent stimulation of labeling relative to controls, calculated from the formula, $E-C_{0}$ l $\mathrm{C}_{1}-\mathrm{C}_{0} \times 100 \%$. Data are expressed as mean \pm S.E.M. Statistical significance was determined by a two-tailed Student's $t$-test.

\section{RESULTS}

Chromaffin cells preincubated with ${ }^{32} \mathrm{P}_{\mathrm{i}}$ and $\left[{ }^{3} \mathrm{H}\right]$ glycerol incorporated both labeled precursors into several phospholipids, including $\mathrm{PhA}, \mathrm{PhI}$, phosphatidylethanolamine, phosphatidylcholine, and the polyphosphoinositides (phosphatidylinositol phosphate and -diphosphate). The relative amounts of radioactivity in each phospholipid varied somewhat with the chromaffin cell preparation and the age of culture. Irrespective of the basal (unstimulated) labeling pattern, the addition of carbachol consistently induced a selective stimulation of incorporation of both ${ }^{32} P_{1}$ and $\left[{ }^{3} \mathrm{H}\right]$ glycerol into $\mathrm{PhA}$ and $\mathrm{PhI}$, which was evident at 2-5 min of incubation (Fig. 1). In five separate experiments, the mean increase in PhA labeling in re- 


\section{Phosphatidic acid}
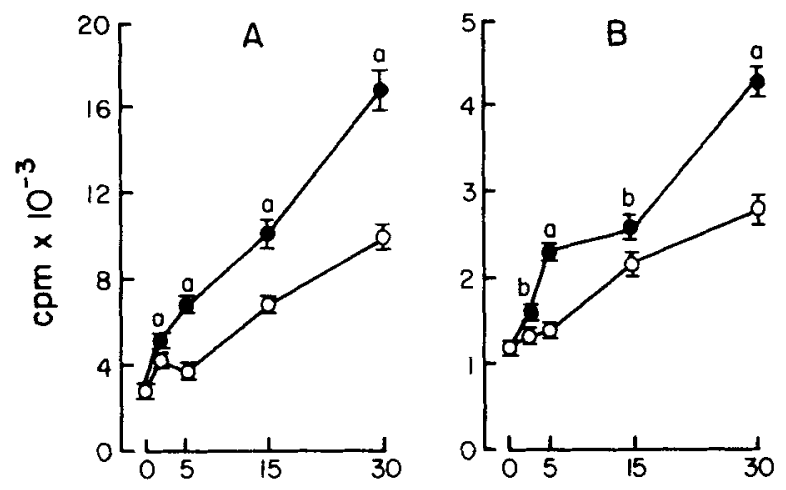

\section{Phosphatidylinositol}

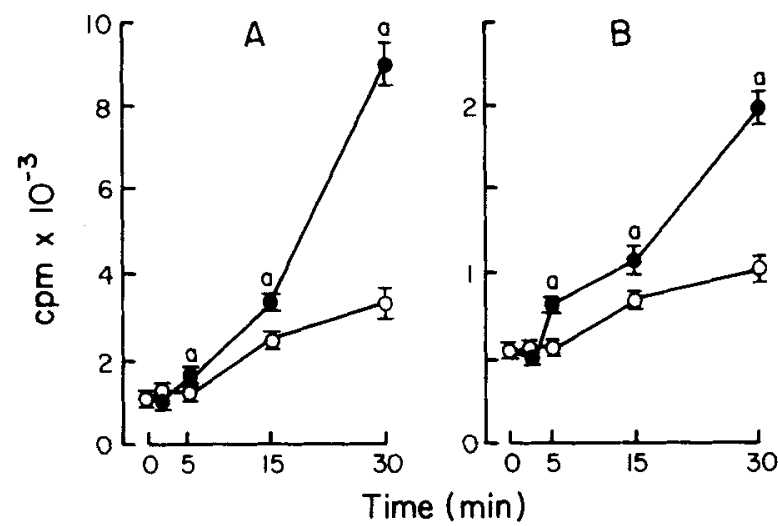

FIG. 1. Time course of incorporation of ${ }^{32} P_{i}(\mathbf{A})$ and [ ${ }^{3} \mathrm{H}$ ]glycerol (B) into PhA and Phl, and the effect of carbachol addition. Chromaffin cells were preincubated for $30 \mathrm{~min}$ at $25^{\circ} \mathrm{C}$ in PSS containing $18.7 \mu \mathrm{Ci}^{32} \mathrm{P}_{i}$ and $22.8 \mu \mathrm{Ci}\left[{ }^{3} \mathrm{H}\right]$ glycerol. After preincubation, the radioactive medium of identical composition with or without carbachol (final concentration 3 $\left.\times 10^{-4} \mathrm{M}\right)$ was added to the wells. Reactions were terminated at $2,5,15$, and $30 \mathrm{~min}$. Five wells were used for each time point and results are expressed as either ${ }^{32} \mathrm{P}$, or $\left[{ }^{3} \mathrm{H}\right] \mathrm{glycerol}$ incorporated into lipid (c.p.m., mean \pm S.E.M.). The basal labeling of PhA and Phl together accounted for $15-25 \%$ of total ${ }^{32} \mathrm{P}_{\mathrm{i}}$ incorporated into lipids and $20-40 \%$ of total $\left[{ }^{3} \mathrm{H}\right]$ glycerol incorporation. $O$. Control incubations, carbachol-treated. Different from control incubations, ${ }^{a} P<$ 0.005, op $<0.02$

sponse to carbachol addition was $266 \pm 31 \%$ for ${ }^{32} \mathrm{P}_{\mathrm{i}}$, and $170 \pm 12 \%$ for $\left[{ }^{3} \mathrm{H}\right] \mathrm{glycerol}$ incorporation. The corresponding values for PhI stimulation were $220 \pm 34 \%$ and $197 \pm 24 \%$. On no occasion did the addition of carbachol to the cultures induce a statistically significant increase in the incorporation of either ${ }^{32} \mathrm{P}_{\mathrm{i}}$ or $\left[{ }^{3} \mathrm{H}\right]$ glycerol into phosphatidylethanolamine, lysophosphatidylethanolamine, or the polyphosphoinositides, although occasionally phosphatidylcholine labeling was also stimulated, especially in prolonged incubations. Lyso PhA was detected in some preparations and its identity verified by twodimensional TLC. When present, its labeling was stimulated to the same extent as PhA by addition of carbachol. There was no detectable labeling of lysophosphatidylcholine in either control or carbachol-treated cultures. To determine whether the catecholamines liberated from the cells by the addition of carbachol were responsible for the stimulation of labeling, a mixture of $20 \mu \mathrm{M}$ epinephrine and $20 \mu \mathrm{M}$-norepinephrine $(5-10$ times the concentration of catecholamine usually liberated into the medium) was added to the cells. No stimulation of either ${ }^{32} \mathrm{P}_{\mathrm{i}}$ or $\left[{ }^{3} \mathrm{H}\right] \mathrm{glycerol}$ incorporation into phospholipids occurred $(93-96 \%$ of control), indicating that the released neurohumors were not directly responsible for the stimulation of phospholipid labeling.

To determine whether the activation of muscarinic or of nicotinic receptors was responsible for the observed changes in phospholipid labeling, a series of experiments was performed using specific agonists and antagonists. Only muscarinic agonists such as muscarine and methacholine $\left(3 \times 10^{-4} \mathrm{M}\right)$ were as effective as carbachol (see above) in the stimulation of PhA and PhI labeling (Table 1). As in the case of carbachol, the addition of muscarinic agonists resulted in an enhanced incorporation of both ${ }^{32} \mathrm{P}_{\mathrm{i}}$ and $\left[{ }^{3} \mathrm{H}\right]$ glycerol, indicating an increased de novo synthesis of these lipids. Of the nicotinic agonists tested, the addition of nicotine or DMPP at concentrations optimal for catecholamine secretion $\left(10^{-5} \mathrm{M}\right)$ had little or no effect on phospholipid labeling. The addition of higher concentrations of nicotine or DMPP $\left(3 \times 10^{-4} \mathrm{M}\right)$ also failed to alter lipid labeling. In contrast, the secretion of catecholamines from chromaffin cells occurred to the same magnitude in the presence of nicotinic agonists $\left(10^{-5} \mathrm{M}\right)$ or carbachol $\left(3 \times 10^{-4} \mathrm{M}\right)$, whereas muscarinic agonists such as muscarine, methacholine, and bethanechol $\left(3 \times 10^{-4} \mathrm{M}\right)$ had no effect (Table 1). Further evidence for a different pharmacological specificity of stimulated phospholipid labeling and catecholamine secretion was obtained from experiments with muscarinic and nicotinic antagonists. Carbachol-stimulated labeling of both $\mathrm{PhA}$ and $\mathrm{PhI}$ was fully reversed by inclusion of $10^{-6} \mathrm{M}$-atropine, whereas the addition of a 40 -fold higher concentration of $d$-tubocurarine $\left(4 \times 10^{-5} \mathrm{M}\right)$ had no statistically significant effect on stimulated labeling. In contrast, the secretion of catecholamines was unaffected by $10^{-6} \mathrm{M}$-atropine, but was inhibited by more than $65 \%$ by the addition of $4 \times 10^{-5} \mathrm{M}-d$ tubocurarine (Table 1).

Both carbachol-stimulated phospholipid labeling and catecholamine secretion were dependent on the availability of calcium, but in different ways. The omission of calcium from PSS resulted in an increase in the basal (unstimulated) labeling of PhI, and in a variable increase in that of $\mathrm{PhA}$. The car- 
TABLE 1. Cholinergic aspects of phospholipid labeling, catecholamine secretion, and calcium influx

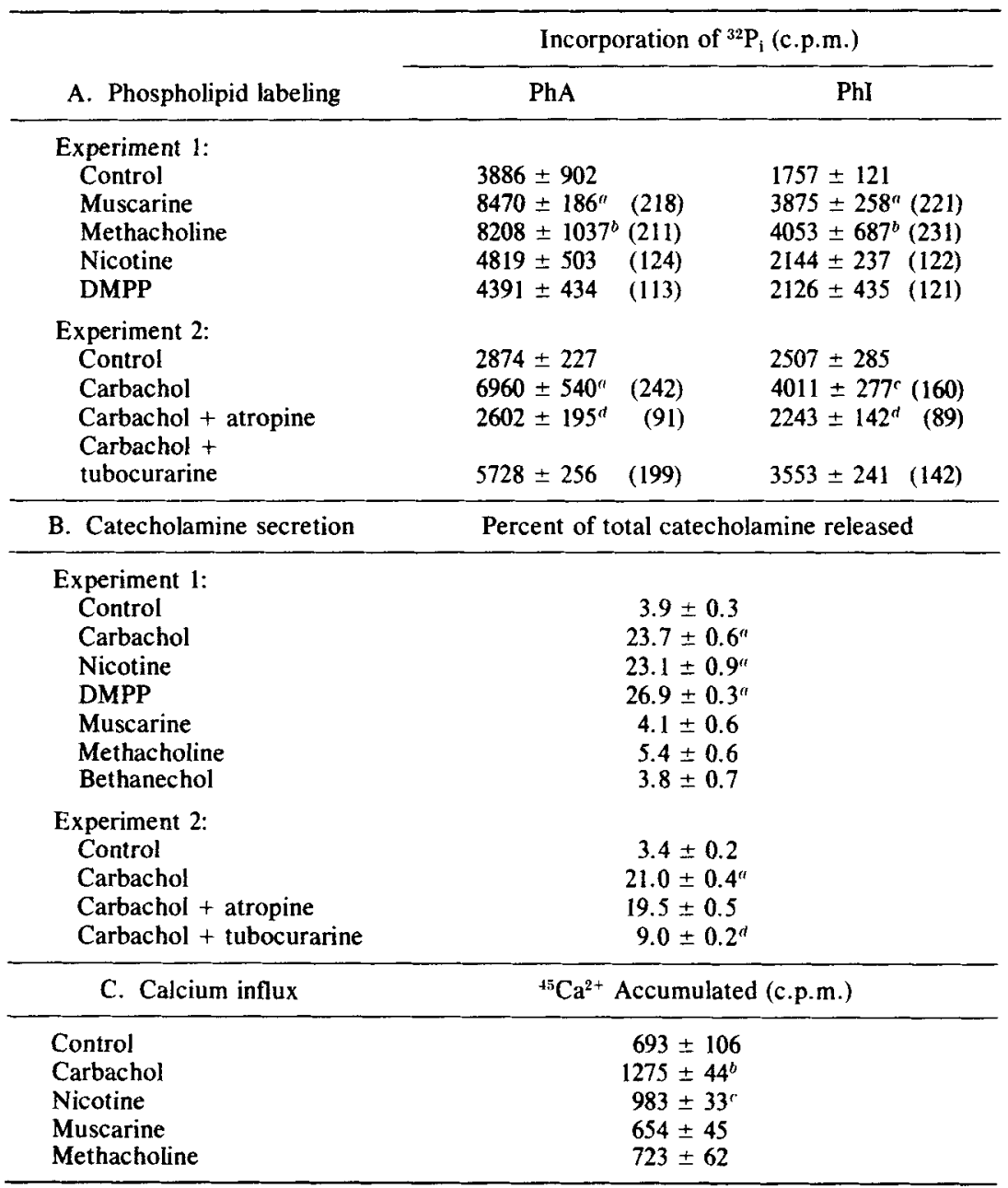

For phospholipid labeling, chromaffin cell cultures were preincubated for $30 \mathrm{~min}$ at $25^{\circ} \mathrm{C}$ in PSS containing $25-45 \mu \mathrm{Ci}^{32} \mathrm{P}_{\mathrm{i}}$. After preincubation, the radioactive medium was aspirated and replaced with fresh radioactive medium with or without drugs. Results are expressed as ${ }^{32} \mathrm{P}_{\mathrm{i}}$ incorporated into $\mathrm{PhA}$ and $\mathrm{PhI}$ during the 15-min incubation period (3-5 wells/group) and the percentage stimulation of labeling relative to control is indicated in parentheses. Neither $d$-tubocurarine nor atropine had any significant effect on phospholipid labeling when added alone. Results from two separate experiments are shown. Three additional experiments gave essentially similar results. Catecholamine release was measured over a 15 -min period in the presence or absence of drugs as indicated ( 3 wells/group). Calcium influx was measured over a 5 -min period ( 3 wells/group). Final concentrations of agonists and antagonists were as follows $(\mathrm{M})$ : carbachol $\left(3 \times 10^{-4}\right)$; muscarine $\left(3 \times 10^{-4}\right)$; methacholine $(3 \times$ $\left.10^{-4}\right)$; bethanechol $\left(3 \times 10^{-4}\right)$; nicotine $\left(10^{-5}\right)$; DMPP $\left(10^{-5}\right)$; atropine $\left(10^{-6}\right) ; d$-tubocurarine $\left(4 \times 10^{-5}\right)$.

Different from control, ${ }^{a} P<0.005 ;{ }^{b} P<0.02 ;{ }^{\circ} P<0.01$; ${ }^{d}$ different from carbacholtreated, $P<0.02$.

bachol stimulation of phospholipid labeling was only minimally reduced by the omission of calcium, but was severely inhibited by the presence of EGTA (Fig. 2). In contrast, catecholamine secretion showed an absolute dependence on the presence of calcium in the medium, and could not be detected either in the absence of added calcium or in the presence of EGTA (Fig. 2). Whereas the addition of carbachol or nicotine resulted in a $40-80 \%$ stimulation of ${ }^{45} \mathrm{Ca}^{2+}$ influx into chromaffin cells, muscarinic agonists had no measurable effect (Table 1).

Further evidence to dissociate the phospholipid labeling effect from secretion was obtained in experiments in which elevation of extracellular $\mathrm{K}^{+}$ concentrations by substitution of the standard incubation medium containing $5.6 \mathrm{~mm}-\mathrm{K}^{+}$and 142 
Phosphatidic acid

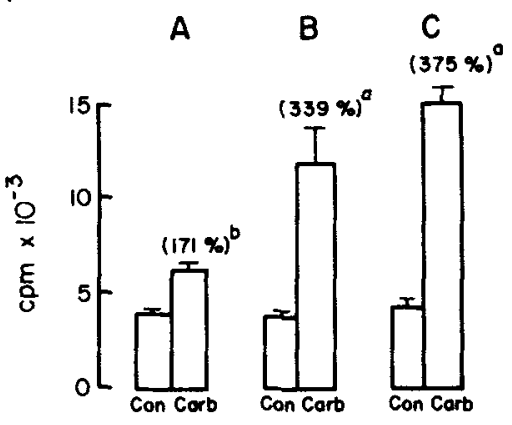

Phosphatidylinositol

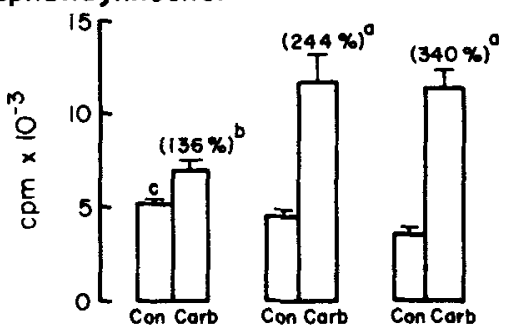

Cafecholamine secretion

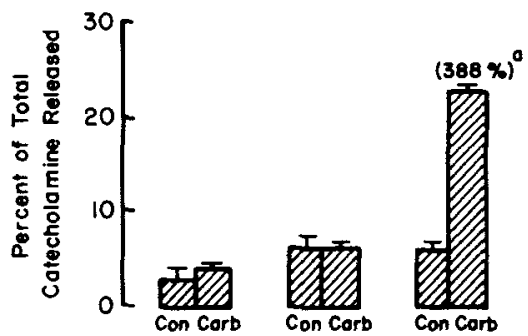

FIG. 2. Effect of calcium omission and calcium chelators on carbachol-stimulated phospholipid labeling and catecholamine release. For phospholipid labeling studies, the cells were preincubated for $30 \mathrm{~min}$ at $25^{\circ} \mathrm{C}$ in PSS containing 40.9 $\mu \mathrm{Ci}{ }^{32} \mathrm{P}_{\mathrm{i}}$. After preincubation, the wells were rapidly washed with $0.5 \mathrm{ml}$ of nonradioactive PSS solution containing (A) 0.5 mM-EGTA, $0 \mathrm{~mm}$-calcium; (B) $0 \mathrm{~mm}$-EGTA, $0 \mathrm{~mm}$-calcium; or (C) $2.2 \mathrm{~mm}$-calcium. Fresh radioactive medium containing the above compositions of calcium and/or chelator, with carbachol $\left(3 \times 10^{-4} \mathrm{M}\right)$ or without (control) was then added and incubations allowed to proceed for $15 \mathrm{~min}$. There were 4-5 wells/group. Results are from one of three experiments that gave similar results. Carbachol-induced catecholamine release from chromaffin cells was measured over a 15-min incubation period, in the presence of calcium and EGTA as indicated. There were 3 wells/group. Numbers in parentheses refer to percent stimulation of labeling or catecholamine release relative to control, where the increases were statistically significant. Different from appropriate control, ap $<$ $0.005 ;{ }^{b P}<0.02$. ${ }^{\mathrm{C} D i f f e r e n t}$ from basal labeling of $\mathrm{Phl}$ in the presence of $2.2 \mathrm{mM}$-calcium, $P<0.05$.

$\mathrm{mM}-\mathrm{Na}^{+}$with one containing $56 \mathrm{mM}-\mathrm{K}^{+}$and 92 $\mathrm{mM}-\mathrm{Na}^{+}$resulted in an induction of catecholamine release $(14 \pm 1 \%$ of total cell catecholamine content, $P<0.001$ ), but had no significant effect on the incorporation of either ${ }^{32} \mathrm{P}$ or $\left[{ }^{3} \mathrm{H}\right] \mathrm{glycerol}$ into $\mathrm{PhA}$ or $\mathrm{PhI}(93-114 \%$ of control).

\section{DISCUSSION}

The present study indicates a pharmacological distinction between the secretory response of bovine chromaffin cell preparations, which is mediated only through nicotinic cholinergic receptors, and stimulated phospholipid labeling, which, as in other tissues, is linked to muscarinic cholinergic receptors (Michell, 1975; Hawthorne and Pickard, 1979; Fisher and Agranoff, 1980). Thus in this experimental preparation, stimulated phospholipid labeling appears to be neither a prerequisite for nor a consequence of secretion.

In addition to differences in pharmacological specificity, separate roles for calcium in catecholamine secretion and phospholipid labeling also distinguish the two processes. The addition of EGTA to a calcium-free medium was required to reduce stimulated phospholipid labeling $75-85 \%$, whereas a calcium-free medium alone caused little inhibition. In contrast, catecholamine secretion was completely inhibited in the $\mathrm{Ca}^{2+}$-free medium in the absence of EGTA. The effect of EGTA on stimulated phospholipid labeling may result from removal of tightly bound $\mathrm{Ca}^{2+}$ from the cell surface or by acceleration of loss of intracellular $\mathrm{Ca}^{2+}$. The finding that conditions for muscarinic stimulation of phospholipid labeling did not result in a measurable stimulation of ${ }^{45} \mathrm{Ca}^{2+}$ influx into the cells whereas nicotinic agents did supports the view that medium calcium enters the cell during nicotinic stimulation to induce exocytosis and further supports the premise that the muscarinic receptor is not coupled to the enhancement of catecholamine secretion.

The conclusion that catecholamine secretion and stimulated phospholipid labeling are not correlated is in agreement with an earlier study by Trifaro $(1969 a, b)$, who used bovine adrenal medulla slices. Although no pharmacological differentiation was made in that study, a distinction between the two processes was inferred on the basis of their respective time courses and the effects of calcium omission. The results obtained with the chromaffin cell culture in the present study differ, however, from those obtained with slices in several aspects. First, the stimulation of $\mathrm{PhA}$ and $\mathrm{PhI}$ labeling in chromaffin cells is considerably more rapid than that observed in slices, presumably as a result of rapid exposure of receptors on cultured cells to the ligand. Thus, stimulated $\mathrm{PhA}$ and $\mathrm{PhI}$ labeling was detected as early as $1 \mathrm{~min}$ after carbachol addition to the chromaffin cell preparation, compared with 10-20 min in the adrenal medulla slices. Since catecholamine secretion from the chromaffin cells also begins within $1 \mathrm{~min}$ of the addition of carbachol (Holz, unpublished observations), a temporal distinction between the onset of stimulated phospholipid labeling and the onset of catecholamine secretion cannot be made. Second, the carbachol-me- 
diated increase in ${ }^{32} \mathrm{P}_{\mathrm{i}}$ incorporation into $\mathrm{PhA}$ and $\mathrm{PhI}$ in chromaffin cells is at least partly the result of increased de novo phospholipid synthesis, since incorporation of $\left[{ }^{3} \mathrm{H}\right]$ glycerol is increased. In the slice experiments, only ${ }^{32} \mathrm{P}$ labeling was stimulated (Trifaro, 1969a). Third, while we confirm a calcium requirement for catecholamine secretion, the present results indicate, in contrast to the conclusions of Trifaro, that calcium may also play an important role in stimulated phospholipid labeling of chromaffin cells, as has been shown previously for the muscarinic stimulation of phospholipid labeling in synaptosomes (Fisher and Agranoff, 1980) and iris smooth muscle (Akhtar and Abdel-Latif, 1978).

The question arises as to whether the muscarinic phospholipid labeling effect could not result from contaminating adrenal cortical cells that are inevitably present in chromaffin cell preparations (Kilpatrick et al., 1980). Adrenal cortical cell preparations support a phospholipid labeling effect in the presence of carbachol (data not shown) and there is some evidence for the presence of intrinsic muscarinic receptors (N. H. Neff, personal communication). However, significantly greater amounts of receptors are found in the adrenal medulla (Kayaalp and Neff, 1979). Further indications for the presence of intrinsic muscarinic receptors in chromaffin cells derive from studies on the elevation by muscarinic agents of cellular cGMP levels in chromaffin cells (Schneider et al., 1979; Lemaire et al., 1980). Kilpatrick et al. (1980) have provided histological evidence that young primary cultures of chromaffin cells were approximately $10 \%$ contaminated with adrenal cortical cells. This value increases with the age of the culture, since the latter cells have superior survival properties. In the present study, however, there was no indication of an increase in the phospholipid labeling effect as either a function of culture age or following cell purification on a Percoll gradient, findings that further argue against the possibility that the observed stimulation of labeling is mediated by adrenal cortical rather than by chromaffin cells.

The present findings then confirm in cultured chromaffin cells the muscarinic nature of the cholinergic phospholipid labeling effect and distinguish it from the nicotinic receptor-mediated exocytotic release of catecholamines.

\section{ACKNOWLEDGMENTS}

This work was supported by NIH grant NS 15413 (to B.W.A.) and grants from the Michigan Heart Association, Michigan-Memorial Phoenix Project, and the National Science Foundation BNS 7824494 (to R.W.H.). S.K.F. was supported by NIMH Training grants MH 07417 and $\mathrm{MH}$ 15794-01.

\section{REFERENCES}

Akhtar R. A. and Abdel-Latif A. A. (1978) Calcium ion requirement for acetylcholine-stimulated breakdown of triphosphoinositide in rabbit iris smooth muscle. J. Pharmacol. Exp. Ther. 204, 655-668.

Douglas W. W. (1975) Secremotor control of adrenal medullary secretion: Synaptic membrane and ion events in stimulussecretion coupling in Handbook of Physiology, Vol. 6, Section 7: Endocrinology (Greep R. O. and Astwood E. B. eds), pp. 367-388. American Physiological Society, Washington.

Euler U. S. von and Floding I. (1955) A fluorimetric micromethod for differential estimation of adrenaline and noradrenaline. Acta Physiol. Scand. (Suppl. 118) 33, 45-56.

Fenwick E. M., Fajdiga P. B., Howe N. B. S., and Livett B. G. (1978) Functional and morphological characterization of isolated bovine adrenal medullary cells. J. Cell Biol. 76, $12-30$.

Fisher S. K. and Agranoff B. W. (1980) Calcium and the muscarinic synaptosomal phospholipid labeling effect. $J$. Neurochem. 34, 1231-1240.

Hawthorne J. N. and Pickard M. R. (1979) Phospholipids in synaptic function. J. Neurochem. 32, 5-14.

Hokin L. E. (1968) Dynamic aspects of phospholipids during protein secretion. Int. Rev. Cytol. 23, 187-208.

Hokin M. R. and Hokin L. E. (1953) Enzyme secretion and the incorporation of $\mathrm{P}^{32} \mathrm{into}$ phospholipides of pancreas slices. J. Biol. Chem. 203, 967-977.

Hokin M. R. and Hokin L. E. (1967) The formation and continuous turnover of a fraction of phosphatidic acid on stimulation of $\mathrm{NaCl}$ secretion by acetylcholine in the salt gland. $J$. Gen. Physiol. 50, 793-811.

Hokin M. R., Benfy B. G., and Hokin L. E. (1958) Phospholipides and adrenaline secretion in guinea pig adrenal medulla. J. Biol. Chem. 233, 814-817.

Kayaalp S. O. and Neff N. H. (1979) Cholinergic muscarinic receptors of bovine adrenal medulla. Neuropharmacology 18 , 909-911.

Kilpatrick D. L., Ledbetter F. H., Carson K. A.. Kirshner A. G., Slepetis R., and Kirshner N. (1980) Stability of bovine adrenal medulla cells in culture. $J$. Neurochem. 35, 679-692.

Lemaire S., Derome G., Tseng R., Mercier P., and Lemaire I. (1980) Muscarinic regulation of cyclic GMP levels and catecholamine secretion in isolated bovine adrenal chromaffin cells. Abstr. Soc. Neurosci. 6, 644.

Livett, B. G., Kozousek, V., Mizobe, F., and Dean, D. M. (1979) Substance P inhibits nicotinic activation of chromaffin cells. Nature 278, 256-257.

Marggraf W.-D. (1976) A biosynthetic method for the preparation of high specific activity ${ }^{32}$ P-labeled phospholipids. $J$. Lipid Res. 17, 622-628.

Michell R. H. (1975) Inositol phospholipids and cell surface receptor function. Biochim. Biophys. Acta 415, 81-147.

Oron Y., Lowe M., and Selinger Z. (1975) Incorporation of inorganic $\left.{ }^{[3} \mathrm{P}\right]$ phosphate into rat parotid phosphatidylinositol. Induction through activation of alpha adrenergic and cholinergic receptors and relation to $\mathrm{K}^{-}$release. $\mathrm{Mol}$. Pharmacol. 11, 79-86.

Schacht J. and Agranoff, B. W. (1972) Effects of acetylcholine on labeling of phosphatidate and phosphoinositides by ${ }^{32} \mathrm{P}$ orthophosphate in nerve ending fractions of guinea pig cortex. J. Biol. Chem. 247, 771-777.

Schneider A. S., Cline H. T., and Lemaire S. (1979) Rapid rise in cyclic GMP accompanies catecholamine secretion in suspensions of isolated adrenal chromaffin cells. Life Sci. 24, $1389-1394$.

Trifaro J. M. (1969a) Phospholipid metabolism and adrenal medullary activity. 1. The effect of acetylcholine on tissue 
uptake and incorporation of orthophosphate- ${ }^{32} \mathrm{P}$ into nucleotides and phospholipids of bovine adrenal medulla. Mol. Pharmacol. 5, 382-393.

Trifaro J. M. (1969b) The effect of $\mathrm{Ca}$ omission on the secretion of catecholamines and the incorporation of orthophosphate- ${ }^{32} \mathrm{P}$ into nucleotides and phospholipids by bovine adrenal medulla during acetylcholine stimulation. Mol. Pharmacol. 5, 424-427.

Trifaro, J. M. and Lee, R. W. H. (1980) Morphological characteristics and stimulus-secretion coupling in bovine adrenal chromaffin cell cultures. Neuroscience 5, 1533-1546.

Yavin E. and Zutra A. (1977) A simple and rapid two directional thin layer chromatography procedure for the separation and analysis of ${ }^{32} \mathrm{P}$-labeled phospholipids from cultured cells. Anal. Biochem. 80, 430-437.

Young, P. W., Bicknell, R. J., and Schofield, J. G. (1979) Acetylcholine stimulates growth hormone secretion, phosphatidylinositol labelling. ${ }^{5 .} \mathrm{Ca}^{2-}$ efflux and cyclic GMP accumulation in bovine anterior pituitary glands. $J$. Endocrinol. 80, 203-213. 